\title{
Expression of $\beta_{1}$ - and $\beta_{3}$-adrenergic-receptor messages and adenylate cyclase $\beta$-adrenergic response in bovine perirenal adipose tissue during its transformation from brown into white fat
}

\author{
Louis CASTEILLA, ${ }^{\star} \ddagger$ Patrick MUZZIN, $\dagger$ Jean-Pierre REVELLI, $\dagger$ Daniel RICQUIER ${ }^{\star}$ and Jean-Paul GIACOBINO $\dagger$ \\ *Centre de Recherche sur l'Endocrinologie moléculaire et le Développement, CNRS, 92190 Meudon, France, \\ and †Département de Biochimie Médicale, Centre Médical Universitaire, 1211 Genève 4, Switzerland
}

Possible modifications of the $\beta$-adrenergic effector system during the development of bovine perirenal brown adipose tissue (BAT) in utero and its transformation into white-like adipose tissue after birth were studied. The parameters assessed were the level of expression of $\beta_{1}-, \beta_{2}$ - and $\beta_{3}$-adrenergic receptor (AR) mRNAs and the response of the plasma-membrane adenylate cyclase to (-)-isoprenaline and to the $\beta_{3}$-agonist BRL 37344. The $\beta_{3}$-AR mRNA was found to be expressed very early in utero, i.e. before the third month of foetal life. Then it increased dramatically (9-fold) between month 6 of foetal life and birth. A high $\beta_{3}$-AR mRNA level was maintained after birth up to an age of 3 months. After conversion of BAT into white-like adipose tissue, i.e. in the adult bovine, the $\beta_{3}$-AR mRNA expression became small or not detectable, and the $\beta_{1}$-AR mRNA, which was expressed much less than the $\beta_{3}$-AR mRNA in foetal life, became predominant. A response of the adenylate cyclase to (-)-isoprenaline was observed in foetal life (3.1-fold stimulation). It decreased after birth (1.8-fold stimulation) and then remained constant until adulthood. A response to BRL 37344 was also observed in foetal life (1.8-fold stimulation). It was maintained after birth, but disappeared in the adult. A possible relationship between the $\beta$-AR expression and the adenylate cyclase response to (-)-isoprenaline on the one hand and the uncoupling-protein expression on the other is discussed. The bovine might represent a good model to understand the transition from brown to white fat in the human.

\section{INTRODUCTION}

In rodents, the biological importance of brown adipose tissue (BAT) as a thermogenic effector throughout life has been clearly demonstrated. This tissue plays a crucial role in the thermoregulation of newborns [1] and contributes to the overall energy expenditure in the adults [2]. BAT is under control of the sympathetic nervous system, which mainly acts via $\beta$-adrenergic receptors $(\beta$-AR) [3]. One of the rate-limiting steps of BAT thermogenesis is a mitochondrial protein, unique to brown adipocytes, called uncoupling protein (UCP). The expression of this protein is regulated at the transcriptional level by catecholamines [4]. UCP can be used as a powerful marker to distinguish between brown and white adipocytes [5].

In large mammals, including ruminants and humans, the importance of BAT in adult life is still an open question. In these species BAT appears during foetal life and is present at birth in most fat-pads, as evidenced by specific BAT features, i.e. typical mitochondria, UCP expression and iodothyronine 5 '-deiodinase activity [6-9]. BAT is involved in thermoregulation in newborns, as in rodents, and is then gradually converted into white-like adipose tissue with disappearance of BAT markers [5-9]. A recent study in bovine perirenal fat has shown that UCP mRNA does not appear before month 7 of gestation and disappears a few days after birth [10]. BAT reappearance in adult humans has been observed in increased sympathetic activity [11-13]. These observations question the mechanisms responsible for development in utero of brown fat at thermoneutral temperature and for its transformation after birth into white-like adipose tissue. The bovine was chosen as a good model for the understanding of adipose-tissue development in ruminants and also in the human.

Recently, a new $\beta$-AR subtype, called $\beta_{3}$-AR, was cloned from human and mouse genomic libraries [14,15] and from rat BAT cDNA libraries $[16,17]$. In rodents, the $\beta_{3}-\mathrm{AR}$ seems to be the predominant $\beta$-AR subtype expressed in BAT, in white adipose tissue (WAT) and in 3T3-F442A adipocytes [16-18]. Its mRNA level was found to be higher in BAT than in WAT and was decreased in both tissues of obese rats, as compared with lean rats [17]. It was shown that the $\beta$-adrenergic stimulation of lipolysis and thermogenesis is mediated essentially in BAT by the $\beta_{3}$-AR [19]. In vivo, chronic stimulation of adults dogs with a $\beta_{3}$ adrenergic agonist ICI D7114 leads to a re-activation of UCP expression in WAT, associated with a decreased weight gain in the animal [20]. In vitro, many experiments demonstrate the efficiency of $\beta_{3}$-adrenergic agonists in promoting differentiation and in increasing UCP mRNA expression in brown adipocytes in primary culture $[21,22]$. Taken together, these results strongly suggest possible relationships between the stimulation of $\beta_{3}$-AR and BAT development.

In this study, we have investigated in the bovine how the development of BAT in utero and its transformation into whitelike adipose tissue after birth is correlated with $\beta$-AR subtype expression. Due to the lack of available labelled $\beta_{3}$-AR ligand, it is at present difficult to measure the amount of $\beta_{3}$-AR protein. We therefore prepared DNA probes for the three $\beta$-AR subtypes and measured the level of the corresponding mRNAs as indexes of their expressions. We also studied the plasma-membrane adenylate cyclase response to $\beta$-adrenergic stimulation.

\section{MATERIALS AND METHODS}

\section{Chemicals}

All organic and inorganic chemicals were of analytical or molecular-biology grade and were purchased from Merck (Darm- 
(a)

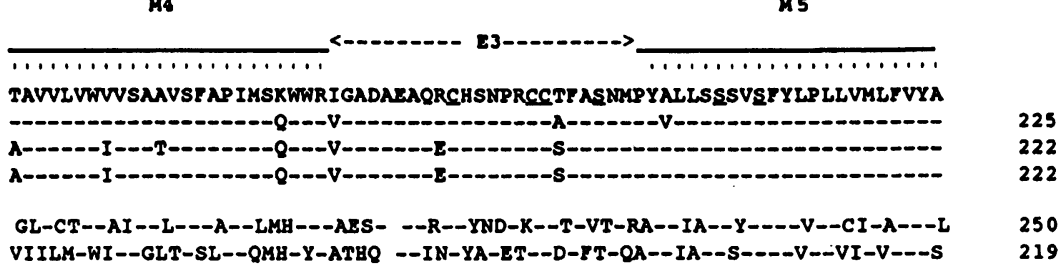

(b)

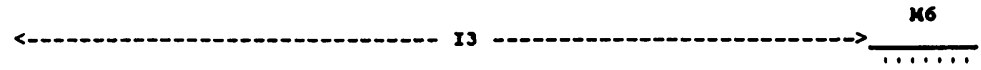

BOV $\beta_{3}$ RVTVATRQLRLLRRELGRPPPERSPPAPSRSGSPGLAGPCASPAGVPSYGRRPARLLPLREERALRTLGLYM

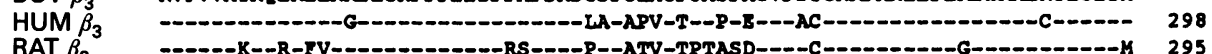

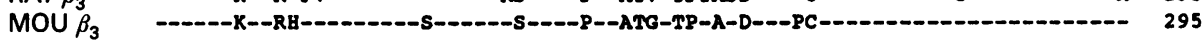

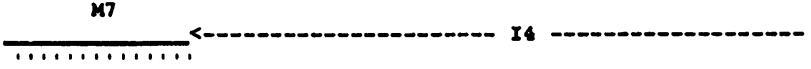

BOV $\beta_{1}$ WLGYNSATNPI IYCRSPDFRKAYORLLCCARRAACGSHAAAGDPPRALGCLAVARPSPS

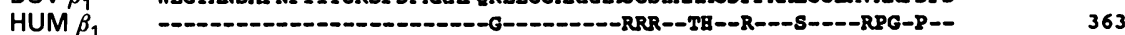

C.

HUM $\beta_{3} \quad$----------L--------S--RR---RCG-RGPPEPC--AR-ALFPSGVPAARSSPA 392 HUM $\beta_{2}$-I--V--G---L----.----I----E---LR-SSLKAYGNGYSSNGNTGEQSGYHVEOEK

I4

BOV $\beta_{1}$ PGAASDDDDDDEDDVGAAPPVRLLEPWAGYNGGAAN"SDSSPDAPSRAGCASESKV

HUM $\beta_{1}$ - -

RAT $\beta_{1}$

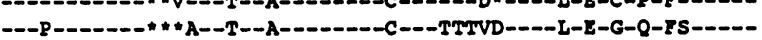

417

467

\section{Figure 1 Amino acid sequences of (a) the bovine (BOV) $\beta_{3}$-AR PCR fragment 501-978 (see the Materials and methods section) and (b) (BOV) $\beta_{1}$-AR PCR} fragment 1174-1614

In (a), alignments with the corresponding regions of the human (HUM) [18], rat (RAT) [21] and mouse (MOU) [19] $\beta_{3}$-AR and with the human $\beta_{1}$-AR [38] and $\beta_{2}$-AR [32] are shown. In (b), alignments with the corresponding regions of the human (HUM) [38] and rat (RAT) [39] $\beta_{1}$-AR and with the human $\beta_{3}$-AR [18] and $\beta_{2}$-AR [32] are shown. M4-M7, transmembrane domains 4-7; E3, extracellular loop 3; 13 and 14, intracellular loops 3 and 4.

stadt, Germany), Sigma (St. Louis, MO, U.S.A.), Fluke (Buchs, Switzerland), Gibco BRL (New York, NY, U.S.A.), Pharmacia (Uppsala, Sweden) or Boehringer (Mannheim, Germany). $\left[\alpha{ }^{32} \mathrm{P}\right] \mathrm{dCTP}(3000 \mathrm{Ci} / \mathrm{mmol})$ was purchased from Amersham International (Amersham, Bucks., U.K.). Duralon-UV membranes, First-Strand Synthesis Kit, Pyrococcus furiosus $(P f u)$ DNA polymerase and the Quik-Hyb hybridization mixture were from Stratagene (La Jolla, CA, U.S.A.), and pBluescript plasmids, $T_{2}$ polymerase kit and prepacked oligo(dT)-cellulose columns were from Pharmacia. BRL 37344 was a gift from SmithKline Beecham Pharmaceuticals (Epsom, Surrey, U.K.).

\section{Tissue sampling}

Bovine (Friesian) foetuses, calves and 2-5-year-old cows (referred to in the text as adult bovine) were killed in a slaughter-house. Perirenal adipose tissue was immediately dissected, and a sample was frozen in liquid $\mathrm{N}_{2}$ and stored at $-20^{\circ} \mathrm{C}$ for RNA extraction or membrane preparation.

\section{PCR}

The PCR amplification was performed by adding $250 \mathrm{ng}$ of bovine genomic DNA to $20 \mathrm{mM}$ Tris $/ \mathrm{HCl}, \mathrm{pH} 8.8,10 \mathrm{mM} \mathrm{KCl}$, $6 \mathrm{mM}_{\left(\mathrm{NH}_{4}\right)_{2} \mathrm{SO}_{4}, 1.5 \mathrm{mM} \mathrm{MgCl}}, 3 \%$ (v/v) formamide, $0.1 \%$
Triton X-100, $1 \mu \mathrm{M}$ of each PCR primer and 1.25 units of thermostable DNA polymerase (total volume $50 \mu \mathrm{l}$ ).

To prepare the $\beta_{3}$-AR gene fragment, a sense primer matched with the human $\beta_{3}$-AR gene sequence (GenBank data bank: M29932) from positions 501 to 520 and an antisense primer from positions 958 to 978 were used. To prepare the bovine $\beta_{1}$-AR gene fragment, a sense primer matched with the human $\beta_{1}$-AR gene sequence (GenBank data bank: JO3019) from positions 1174 to 1193 and an antisense primer from positions 1595 to 1614 were used.

The reaction mixture was overlayered with $100 \mu \mathrm{l}$ of mineral oil, and the PCR amplification was performed using a PerkinElmer Cetus DNA Thermal Cycler. After an initial denaturation step of 3 min at $95^{\circ} \mathrm{C}, 30$ cycles were performed, which consisted of denaturation $\left(1 \mathrm{~min}\right.$ at $\left.95^{\circ} \mathrm{C}\right)$, annealing $\left(1.5 \mathrm{~min}\right.$ at $\left.56^{\circ} \mathrm{C}\right)$ and extension $\left(1 \mathrm{~min}\right.$ at $\left.72^{\circ} \mathrm{C}\right)$.

\section{Cloning and sequencing}

PCR products were analysed by electrophoresis on a $2 \%$-agarose gel. Bands of interest were identified by ethidium bromide staining, eluted from the gel and cloned in pBluescript plasmids. Three independent clones of the PCR products obtained with 
each pair of primers were sequenced by using the $T_{7}$ polymerase kit.

\section{RNA extraction and Northern-blot analysis}

Total RNA was isolated from the adipose tissue by the caesium/ trifluoroacetic acid gradient method of Okayama et al. [23]. The poly $(\mathrm{A})^{+}$RNA was isolated from total RNA by the method described by Aviv and Leder [24], by using prepacked oligo(dT)cellulose columns.

Total RNA $(20 \mu \mathrm{g})$ or poly(A) ${ }^{+}$RNA $(15 \mu \mathrm{g})$ was electrophoresed on a $1 \%$-agarose gel containing formaldehyde, as described by Lehrach et al. [25], and transferred to Duralon-UV membranes by capillary blotting. PCR fragments of $\beta_{1}$ - and $\beta_{3^{-}}$ AR obtained from bovine genomic DNA as described above and the entire coding region of the human $\beta_{2}$-AR cDNA (gift from Dr. C. M. Fraser [26]) were labelled by random priming with $[\alpha-$ $\left.{ }^{32} \mathrm{P}\right] \mathrm{dCTP}$ to a specific radioactivity of approx. $1 \times 10^{9} \mathrm{~d}$.p.m. $/ \mu \mathrm{g}$ of DNA and used as probes. RNA blots were hybridized for $1 \mathrm{~h}$ at $68^{\circ} \mathrm{C}$ in the Quik-Hyb hybridization mix, washed in a solution of $0.1 \times \mathrm{SSC}(\mathrm{SSC}=0.15 \mathrm{M} \mathrm{NaCl} / 0.15 \mathrm{M}$ sodium citrate)/ $0.1 \%$ SDS at $65^{\circ} \mathrm{C}$ for $15 \mathrm{~min}$ and exposed to Kodak X-AR films at $-70^{\circ} \mathrm{C}$. Size estimates of the RNA species were established by comparison with an RNA ladder.

\section{Adenylate cyclase studies}

Adipose-tissue plasma membranes were prepared as described previously for rat BAT [27]. Protein concentrations were determined by the method of Lowry et al. [28]. The adenylate cyclase activity of the membranes was measured by the technique described by Cooper et al. [29] in the presence of $10 \mu \mathrm{M}$ GTP.

\section{RESULTS}

\section{Characterization of the $\boldsymbol{\beta}_{3}$ - and $\boldsymbol{\beta}_{1}-$ AR probes}

The amino acid sequence of the $\beta_{3}$-AR fragment obtained by PCR amplification of bovine genomic DNA with appropriate primers is shown in Figure 1(a). This sequence shows a higher degree of similarity to the human [14] than to the rat [17] $\beta_{3}$-AR corresponding sequence ( $89 \%$ and $82 \%$ respectively). It shows a low degree of similarity to the corresponding human $\beta_{1}$-AR [30] and $\beta_{2}$-AR [26] sequences ( $54 \%$ and $43 \%$ respectively). The amino acid sequence of the $\beta_{1}$-AR PCR fragment was found to display the same degree of similarity to the corresponding human [30] and rat [31] $\beta_{1}$-AR sequences (81\%) (Figure $1 \mathrm{~b}$ ).

\section{Developmental changes in the $\beta$-AR mRNA levels}

In the bovine foetus, the largest single depot of adipose tissue is located around the kidney. As early as at month 3 of foetal life (time of gestation in the bovine is 9 months), a small but significant amount of $\beta_{3}$-AR mRNA could be detected in perirenal fat by Northern-blot analysis (results not shown). Figure 2 shows that the $\beta_{3}$-AR mRNA level starts to rise after month 6 of foetal life until birth (9-fold increase). From month 3 of postnatal life it decreases, and is either still detectable, but at a low level, or undetectable, in 3 and 2, respectively, of the 5 adult bovines tested.

As can be measured from Figure 3 , the sizes of $\beta_{1}$ - and $\beta_{2}$-AR mRNA are 3.1 and $2.4 \mathrm{~kb}$ respectively. The sizes of $\beta_{3}$-AR mRNAs are 2.2 and $1.9 \mathrm{~kb} . \beta_{1}, \beta_{2}$ - and $\beta_{3}$-AR mRNA levels were compared in foetal and adult bovine perirenal fat by Northernblot analysis. To increase the sensitivity of the method, poly(A)+ RNA was used as the starting material. At month 8 of foetal life, the $\beta_{1}$-AR mRNA level is lower than that of $\beta_{3}$-AR mRNA (Figure 3). In the adult bovine, however, the $\beta_{1}$-AR mRNA level is higher than that of $\beta_{3}$-AR mRNA (Figure 3 ). In the foetus $\beta_{2}-$ AR mRNA can be detected, but at a much lower level than $\beta_{3}$ - or $\beta_{1}$-AR mRNA. In the adult the $\beta_{2}$ and $\beta_{3}$-AR mRNA are at the same level.

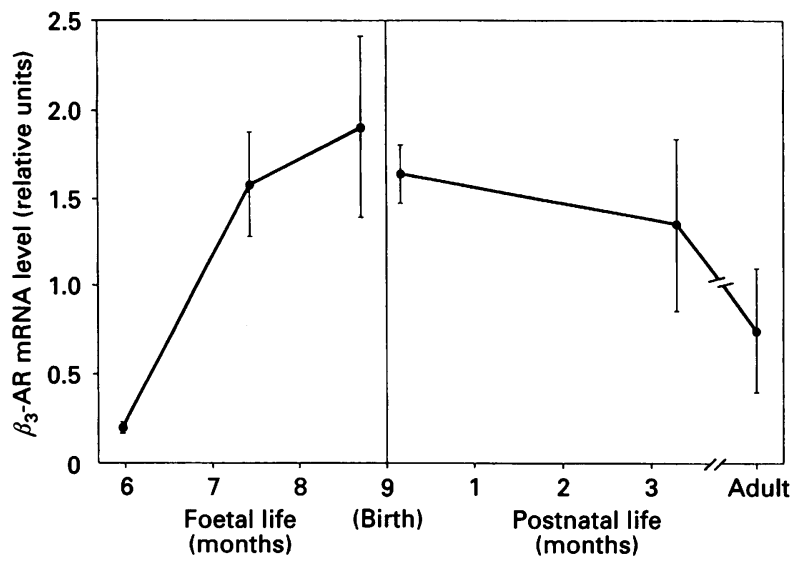

Figure $2 \boldsymbol{\beta}_{3}$-AR mRNA levels in bovine perirenal fat at various times of foetal and postnatal life

Samples ( $30 \mu \mathrm{g}$ ) of RNA were electrophoresed, transferred to membrane filters, hybridized with a ${ }^{32}$ P-labelled bovine $\beta_{3}$-AR genomic DNA probe, and the autoradiographic signals were quantified by densitometric analysis. The results are expressed in relative units. They are means \pm S.E.M. of $3-5$ experiments performed on tissues from 3-5 different animals. The ages at which the samples were obtained are expressed in months.

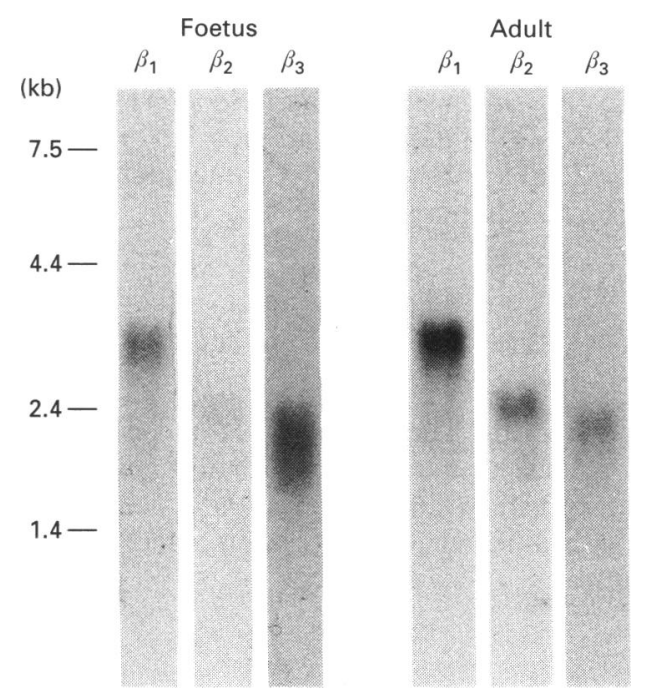

Figure $3 \beta$-AR-subtype mRNA levels in foetal (month 8 of foetal life) and adult bovine perirenal fat

Samples $(15 \mu \mathrm{g})$ of poly $(\mathrm{A})^{+}$RNA were electrophoresed, transferred to membrane filters and hybridized with ${ }^{32}$ P-labelled bovine $\beta_{1}$ - and $\beta_{3}$-AR genomic DNA probes and the human $\beta_{2}$ AR cDNA probe. The representative autoradiograms shown were obtained under identical conditions and with probes of similar specific radioactivities. The positions of the marker RNAS are shown in $\mathrm{kb}$. 
Table 1 Effect of (-)-isoprenaline and BRL 37344 on the adenylate cyclase activity of bovine perirenal-fat plasma membranes

The different times of bovine development chosen are: foetal life (month 8 of foetal life), neonatal life $(10 \pm 3$ days) and adulthood. The results are means \pm S.E.M. of the numbers of experiments in parentheses. They are expressed as percentages of the control value measured in the absence of $\beta$-adrenergic agonist. ${ }^{\star} P<0.05,{ }^{\star \star} P<0.005$ versus the respective value in foetal life.

\begin{tabular}{llc}
\hline & \multicolumn{2}{l}{$\begin{array}{l}\text { Adenylate cyclase activity } \\
\text { (\% of control) }\end{array}$} \\
\cline { 2 - 3 } & $(-)$-Isoprenaline & BRL 37344 \\
\hline Foetal life & $311 \pm 43(4)$ & $177 \pm 19(4)$ \\
Neonatal life & $184 \pm 6(3)^{\star}$ & $163 \pm 7(3)$ \\
Adulthood & $202 \pm 24(4)^{\star}$ & $98 \pm 9(4)^{\star *}$
\end{tabular}

\section{Developmental changes in adenylate cyclase stimulation by (-)-isoprenaline and BRL 37344}

The basal adenylate cyclase activity of perirenal-fat plasma membranes is $35.2 \mathrm{pmol} / \mathrm{min}$ per $\mathrm{mg}$ of protein, and $\mathrm{NaF}$ $(10 \mathrm{mM})$ stimulates this activity 3.3-fold. Basal and NaF-stimulation values were found to be constant at all stages of the development studied.

The response of the adenylate cyclase activity to (-)isoprenaline or BRL 37344 was studied. BRL 37344 is a potent agonist of all $\beta_{3}$-ARs studied until now, including those of human [14] and dog [32]. As may be inferred from results obtained in the rat by Muzzin et al. [33,34], at the concentrations used, (-)-isoprenaline should act via $\beta_{1}-, \beta_{2}$ - and $\beta_{3}$-AR, whereas BRL 37344 should act via $\beta_{3}$-AR. A stimulation of the adenylate cyclase activity by (-)-isoprenaline (1.6-fold; $n=2)$ and by BRL 37344 (1.3-fold; $n=2)$ is already observed at month 6 of foetal life. As shown in Table 1, the maximal response to (-)isoprenaline (3.1-fold stimulation at month 8 of foetal life) decreases significantly after birth (1.8-fold stimulation) and remains practically unchanged until adulthood. The response to BRL 37344 (1.8-fold stimulation) at month 8 of foetal life remains constant after birth (1.6-fold stimulation), but is no longer detectable in adulthood.

\section{DISCUSSION}

In larger mammals, BAT is well developed prenatally and immediately after birth. Then it involutes and is replaced by white fat. It seemed interesting to test in ruminants if the development of brown fat and its transition to white fat during development might be related to possible changes in the $\beta$ adrenergic control.

\section{Bovine $\boldsymbol{\beta}_{3}$ - and $\boldsymbol{\beta}_{1}$-AR probes}

The $\beta_{3}$-AR probe encompasses a domain from trans-membrane region 4 (M4, Figure 1a) to the beginning of trans-membrane region 6 (M6). Its sequence includes cysteine-186, -192, -193 and serine-206 and -209, which play an important role in $\beta$-AR-ligand interaction and the third intracellular loop which confers the specificity of coupling to GTP-binding protein [35].

The $\beta_{1}$-AR probe (Figure $1 \mathrm{~b}$ ) encompasses a domain from the end of the $3^{\prime}$ coding to the beginning of the 3 ' non-coding region. The amino acid sequence corresponds to the cytoplasmic tail of the receptor, which is rich in serine and threonine. These residues may serve as substrates for the $\beta$-AR kinase during the desensitization process [35].

\section{Developmental changes in the $\boldsymbol{\beta}$-AR levels}

In foetal life, perirenal fat is characterized by a high expression of the $\beta_{3}$-AR gene. At this stage of the development the $\beta_{1}$-AR gene is expressed at a low level, and the $\beta_{2}$-AR mRNA is undetectable. Accordingly, a high level of the $\beta_{3}$-AR mRNA has been observed in rat [17] and human child brown fat [36]. It is noteworthy that the appearance of $\beta_{3}$-AR mRNA during foetal life in perirenal fat precedes that of UCP mRNA, which occurs only at month 7 of gestation [10]. A high $\beta_{3}$-AR mRNA level is maintained after birth up to the age of 3 months (Figure 2), at which UCP mRNA level has been reported to be practically undetectable [10]. It is known that, during the first 3 months of life, the number of adipocytes in bovine perirenal fat remains unchanged [37]. The disappearance of UCP mRNA can therefore be considered as an indication that brown adipocytes have been transformed into white-like adipocytes. The question can be asked whether the presence of the $\beta_{3}$-AR mRNA is the witness of a previous brown-fat phenotype, or if the $\beta_{3}$-AR is normally expressed in typical bovine white adipocytes.

The $\beta_{3}$-AR mRNA expression is small or undetectable in the adult bovine (Figure 2). This is in contrast with the results obtained in rodent WAT, where the $\beta_{3}$-AR was found to be highly expressed [17], but in agreement with the results obtained until now in adult human WAT $[36,38]$. Thus the brown-fat to white-like-fat transformation does not necessarily involve the same changes in rodents and in large mammals, and the bovine species might be a good model of what is the real scheme in human.

\section{Developmental changes in adenylate cyclase stimulation by (-)-isoprenaline and BRL 37344}

In this part of the study, (-)-isoprenaline was chosen as a general agonist for all $\beta$-adrenergic subtypes, and BRL 37344 as a specific $\beta_{3}$-adrenergic agonist [14].

The developmental changes in the response of adenylate cyclase to BRL 37344 (Table 1) are rather well correlated with the changes in the $\beta_{3}$-AR mRNA level (Figure 2).

After birth, the adenylate cyclase response to (-)-isoprenaline (Table 1) decreases significantly. At the same time, the UCP mRNA level decreases sharply [10]. These results agree with those of Klein et al. [39] who have reported that the catecholamine response of adipocyte respiration, which increases in ovine species during foetal life, disappears after birth. In the ruminant newborn, parturition is associated with a high neurosympathetic stimulation [40] which could induce a $\beta$-AR desensitization. The decrease in the response of adenylate cyclase to (-)-isoprenaline observed after birth may be due to $\beta_{1}$-AR desensitization. It is noteworthy that there is no change in BRL 37344 response after birth. Granneman [41] reported that exposure of isolated white adipocytes to a concentration of $(-)$-isoprenaline that stimulates the adenylate cyclase via both $\beta_{1}$ - and $\beta_{3}$-ARs induces an uncoupling of the $\beta_{1}-\mathrm{AR}$, but not of the $\beta_{3}-\mathrm{AR}$ response. The results of the present study and those of Granneman [41] suggest that the $\beta_{1}$ - and $\beta_{3}$-AR might not share the same desensitization process.

It is tempting to speculate that the increase in UCP expression in bovine perirenal fat during foetal life is under the control of 
the $\beta_{3}$-adrenergic system, and that the rapid decrease in UCP expression shortly after birth is related to a decrease in the (-)isoprenaline response.

It is proposed that perirenal adipose tissue of the bovine is a good model for studying the brown-to-white adipocyte phenotype change in large mammals, including humans. Factors controlling this change are of importance to understand the development of whole adipose-tissue mass.

We thank Ms Françoise Kühne for excellent technical assistance, and Susi Klaus and Odette Champigny for her helpful discussion. This work was supported by a grant (no. 32-26331-89) from Swiss National Science Foundation, by a grant from INRA (no. 4588), and by grants-in-aid from the Ernst and Lucie Schmidheiny, GeigyJubiläums and Sandoz Foundations. L.C. has been supported by a grant from C.N.R.S.

\section{REFERENCES}

1 Nedergaard, J., Connolly, E. and Cannon, B. (1986) in Brown Adipose Tissue: Brown Adipose Tissue in the Mammalian Neonate (Trayhurn, P. and Nicholls, D. G., eds.), pp. 152-213, Arnold, London

2 Rothwell, N. and Stock, M. J. (1986) in Brown Adipose Tissue: Brown Adipose Tissue and Diet-induced Thermogenesis (Trayhurn, P. and Nicholls, D. G., eds.), pp. 269-298, Arnold, London

3 Himms-Hagen, J. (1990) FASEB J. 11, 2890-2898

4 Ricquier, D., Bouillaud, F., Toumelin, P., Mory, G., Bazin, R., Arch, J. and Penicaud, L. (1986) J. Biol. Chem. 261, 13905-13910

5 Ricquier, D., Casteilla, L. and Bouillaud, F. (1991) FASEB J. 5, 2237-2242

6 Casteilla, L., Forest, C., Robelin, J., Ricquier, D., Lombet, A. and Ailhaud, G. (1987) Am. J. Physiol. 252, E627-E636

7 Vatnick, l., Tyzbir, R. S., Welch, J. G. and Hooper, A. P. (1987) Am. J. Physiol. 252, E391-E395

8 Giralt, M., Casteilla, L., Vinas, 0., Manpel, T., Iglesias, R., Robelin, J. and Villarroya, F. (1989) Biochem. J. 259, 555-559

9 Lean, M. E. J. and James, W. P. T. (1986) in Brown Adipose Tissue: Brown Adipose Tissue in Man (Trayhurn, P. and Nicholls, D. G., eds.), pp. 339-365, Arnold, London

10 Casteilla, L., Champigny, 0., Bouillaud, F., Robelin, J. and Ricquier, D. (1989) Biochem. J. 257, 665-671

11 Huttunen, P., Hittonen, J. and Kinula, V. (1981) Eur. J. Appl. Physiol. 46, 339-345

12 Lean, M. E. J., James, M. P. T., Jennings, G. and Trayhurn, P. (1986) Int. J. Obesity 10, 219-227

13 Ricquier, D., Néchad, M. and Mory, G. (1986) J. Clin. Endocrinol. Metab. 54, 803-807

14 Emorine, L. J., Marullo, S., Briend-Sutren, M. M., Patey, G., Tate, K., DelavierKlutchko, C. and Strosberg, A. D. (1989) Science 245, 1118-1121
15 Nahmias, C., Blin, N., Elalouf, J. M., Mattei, M. G., Strosberg, A. D. and Emorine, L. J. (1991) EMBO J. 10, 3721-3727

16 Granneman, J. G., Lahners, K. N. and Chaudhry, A. (1991) Mol. Pharmacol. 40, $895-899$

17 Muzzin, P., Revelli, J. P., Kuhne, F., Gocayne, J. D., McCombie, W. R., Venter, J. C., Giacobino, J. P. and Fraser, C. M. (1991) J. Biol. Chem. 266, 24053-24058

18 Fève, B., Emorine, L. J., Lasnier, F., Blin, N., Baude, B., Nahmias, C., Strosberg, A. D. and Pairault, J. (1991) J. Biol. Chem. 266, 20329-20336

19 Arch, J. R. S., Ainsworth, A. T., Cawthorne, M. A., Piercy, V., Sennitt, M. V., Thody, V. E., Wilson, C. and Wilson, S. (1984) Nature (London) 309, 163-165

20 Champigny, 0., Ricquier, D., Blondel, 0., Mayers, M. R., Briscoe, M. G. and Holloway, B. R. (1991) Proc. Natl. Acad. Sci. U.S.A. 88, 10774-10777

21 Klaus, S., Cassard, A. M. and Ricquier, D. (1991) J. Cell Biol. 115, 1783-1790

22 Champigny, O., Holloway, B. R. and Ricquier, D. (1992) Mol. Cell. Endocrinol. 86, 73-82

23 Okayama, H., Kawaichi, M., Brownstein, M., Lee, F., Yokota, T. and Atai, K. (1987) Methods Enzymol. 154, 3-28

24 Aviv, H. and Leder, P. (1972) Proc. Natl. Acad. Sci. U.S.A. 69, 1408-1412

25 Lehrach, H., Diamond, D., Wozney, J. M. and Boedtker, H. (1977) Biochemistry 16, $4743-4751$

26 Chung, F. Z., Lentes, U. K., Gocayne, J., Fitzgerald, M., Robinson, D., Kerlavage, A. R., Fraser, C. M. and Venter, J. C. (1987) FEBS Lett. 211, 200-206

27 Giacobino, J. P. (1979) J. Supramol. Struct. 11, 445-449

28 Lowry, 0. H., Rosebrough, N. J., Farr, A. L. and Randall, R. J. (1951) J. Biol. Chem. 193, 265-275

29 Cooper, D. M. F., Schlegel, W., Lin, M. C. and Rodbell, M. (1979) J. Biol. Chem. 254, 8927-8931

30 Frielle, T., Collins, S., Daniel, K. W., Caron, M. G., Lefkowitz, R. J. and Kobilka, B. K. (1987) Proc. Natl. Acad. Sci. U.S.A. 84, 7920-7924

31 Machida, C. A., Bunzow, J. R., Searles, R. P., Van Tol., H., Tester, B., Neve, K. A. Teal, P., Nipper, V. and Civelli, O. (1990) J. Biol. Chem. 265, 12960-12965

32 Langin, D., Portillo, M. P., Saulnier-Blache, J. S. and Lafontan, M. (1991) Eur. J. Pharmacol. 199, 291-301

33 Muzzin, P., Seydoux, J., Giacobino, J. P., Venter, J. C. and Fraser, C. (1988) Biochem. Biophys. Res. Commun. 156, 375-382

34 Muzzin, P., Revelli, J. P., Frazer, C. M. and Giacobino, J. P. (1992) FEBS Lett. 298, $162-164$

35 Lefkowitz, R. J. and Caron, M. G. (1988) J. Biol. Chem. 263, 4993-4996

36 Krief, S., Lönnqvist, F., Raimbault, S., Baude, B., Arner, P., Strosberg, A. D., Ricquier, D. and Emorine, L. J. (1993) J. Clin. Invest. 91, 344-349

37 Robelin, J. (1981) J. Lip. Res. 22, 452-457

38 Revelli, J. P., Muzzin, P., Paoloni, A., Moinat, M. and Giacobino, J. P. (1993) J. Mol. Endocrinol. 10, 193-197

39 Klein, A. H., Reviczky, A., Chou, P., Padbury, J. and Fisher, D. A. (1983) Endocrinology (Baltimore) 112, 1662-1666

40 Padbury, J. F., Diakomanolis, E. S., Hobel, C. J., Perelman, A. and Fisher, D. A. (1981) Pediatr. Res. 15, 1483-1487

41 Granneman, J. G. (1992) J. Pharmacol. Exp. Ther. 261, 638-642

Received 10 June 1993/18 August 1993; accepted 27 August 1993 